\title{
Capital humano e câmbio
}

Luciano Nakabashi*

O crescimento das economias asiáticas, principalmente da China, vem alterando o peso econômico e o mapa geopolítico mundial. O bom desempenho da economia chinesa de forma sustentável, além da perspectiva de que esse crescimento continue por um longo período, vem causando uma mudança em sua importância econômica mundial, além de uma maior dependência de vários países em relação à sua demanda.

Esse cenário fica ainda mais claro quando se considera a crise internacional de 20072009, onde a China apresentou um papel relevante para que ela (a crise) não se tornasse ainda mais profunda. O forte crescimento da economia chinesa, mesmo no período mais crítico da crise, foi de extrema relevância para manter o dinamismo das exportações de vários países, contribuindo para que os mesmos atravessassem esse período de forma mais suave.

Essa demanda foi importante, até mesmo, para os países da América do Sul, inclusive para o Brasil. A pauta de exportações deste vem se tornando cada vez mais dependente da demanda chinesa e dos países asiáticos em geral. No entanto, a demanda chinesa de produtos provenientes do Brasil e do restante da América do Sul é concentrada em bens de baixo valor agregado e baixo conteúdo tecnológico, o que pode ter impacto no dinamismo econômico. Um bom exemplo é o fato de que, de acordo com dados da SECEX, as vendas das cinco principais commodities exportadas pelo Brasil - minério de ferro, petróleo bruto, soja (grão, farelo e óleo), açúcar (bruto e refinado) e complexo carnes - representaram 43,4\% das exportações brasileiras, em 2010.

Adicionalmente, os dados apontam que os bens manufaturados e industrializados estão perdendo participação na pauta de exportações, com significativa elevação dos básicos. Em abril de 2010, a participação destes ultrapassou a dos manufaturados e essa diferença vem se elevando lentamente. Outra evidência relevante é que nos primeiros três meses de 2011 as exportações industriais de alta e média-alta tecnologia registraram déficit de US\$17,7 bilhões, superando em mais de US $\$ 5$ bilhões o valor de 2010, e correspondendo ao dobro do registrado em 2008 e 2009, considerando os primeiros três meses de cada ano.

Por sua vez, mudanças na pauta de exportações tendem a provocar mudanças na estrutura de produção das economias. Se os setores mais prejudicados pela valorização cambial

* Doutor em Economia pela Universidade Federal de Minas Gerais. É professor do Departamento de Economia da Universidade Federal do Paraná e pesquisador do CNPq. Endereço eletrônico: luciano.nakabashi@gmail.com. 
forem justamente aqueles mais dinâmicos e com níveis mais elevados de encadeamentos, os impactos sobre o crescimento de longo prazo serão negativos. No caso brasileiro, os segmentos mais afetados parecem ser aqueles mais intensivos em tecnologia. Essa evidência aponta que o desenvolvimento destes ocorreu com base em políticas protecionistas com o argumento de indústria nascente, mas as mudanças estruturais necessárias para que eles se tornassem competitivos não ocorreram.

Esse processo de mudança na pauta de exportação ocorre, por um lado, porque há uma crescente demanda internacional por produtos básicos, o que estimula a produção dos mesmos na economia. Por outro, o crescimento das exportações desses bens ajuda à apreciação da taxa de câmbio, com impactos negativos na exportação e produção de bens que não experimentam significativa elevação da demanda mundial.

No entanto, apesar de ser uma variável estratégica e relevante, apenas um câmbio mais depreciado não é suficiente para estimular os demais segmentos da indústria, principalmente daqueles com maior conteúdo tecnológico. Fatores somente conjunturais não podem criar as condições para um crescimento sustentável. Para elevar a competitividade de maneira sólida e com efeitos permanentes é preciso investir em capital humano e tecnologia, sendo que vários estudos mostram que existe uma elevada correlação entre estas duas variáveis.

Investimentos na capacitação das pessoas aumentam a produtividade de forma direta, além de estimular o processo de difusão de tecnologia, pois pessoas com maior nível de qualificação possuem maior capacitação para receber, decodificar e entender informações. O processamento e interpretação dessas informações são cruciais na execução de novas atividades e para aprender a executar tarefas mais complexas, como ressaltado pelos ecomistas Richard Nelson e Edmund Phelps, ambos da Universidade de Columbia. O processo de difusão de tecnologia é essencial para elevar a competitividade externa e aumentar o PIB per capita.

Em outras palavras, o país obteve sucesso em implementar atividades industriais complexas no período de industrialização via substituição de importações, mas isso ocorreu sem um acompanhamento satisfatório no grau médio de qualificação de seus trabalhadores e, desse modo, sem grandes ganhos de competitividade. Nesse caso, como há uma expectativa de que a China continue a elevar a sua importância na economia mundial e com efeitos duradouros na demanda por produtos básicos, visto sua baixa renda per capita e o tamanho da sua população, restará ao país observar o ganho de importância desses bens em sua pauta de exportação e na estrutura produtiva da economia.

Para reverter esse cenário ou mesmo aproveitá-lo melhor, é essencial o investimento em capital humano e tecnologia. Desse modo, os formuladores de política econômica precisam 
prestar atenção não somente ao nível da taxa de câmbio, mas principalmente ao grau de qualificação dos trabalhadores, de forma a propiciar competitividade genuína, ou seja, aquela baseada na dotação de fatores relevantes para os segmentos mais intensivos em tecnologia. Adicionalmente, esses investimentos proporcionam um maior potencial de aproveitamento da mudança na economia mundial ao possibilitar a produção de bens interligados ao setor primário, mas com maior nível de valor agregado. O próprio processo de capacitação dos trabalhadores seria relevante para aumentar o processo de difusão de tecnologias provenientes de países desenvolvidos.

Assim, mudanças na economia mundial devem ser associadas a políticas cambiais que sejam benéficas para o desempenho econômico no longo prazo, mas sem esquecer que as mesmas devem vir acompanhadas de investimentos significativos para elevar, sobretudo, a qualidade do capital humano médio dos trabalhadores brasileiros e a tecnologia disponível. Todas essas relações são de suma importância para darem sustentação a políticas econômicas que sejam adotadas visando o crescimento, de forma sustentável, do PIB per capita. 
